\title{
Effects of herbal multicomponent dietary supplement in experimental pneumonia
}

\author{
Z. Serebrovska1, R. Swanson², V. Portnichenko1, A. Shysh', \\ L. Tumanovska ${ }^{1}$, A. Dorovskych ${ }^{3}$, V.Dosenko $^{1}$ \\ ${ }^{1}$ Bogomoletz institute of Physiology, National Academy of Sciences of Ukraine, Kyiv; \\ e-mail: belyak-serebrovska@hotmail.com; \\ ${ }^{2}$ Liberty University College of Osteopathic Medicine, Lynchburg, USA; \\ ${ }^{3}$ Integrative Medicine Clinic "SmartMed", Kyiv, Ukraine
}

\begin{abstract}
We investigated the multi-component herbal dietary supplement, which contains extracts of 19 medicinal plants traditionally used as anti-inflammatory remedies. Here we have investigated the effects of this supplement on lung tissue morphology, reactive oxygen species (ROS) generation in blood, lung tissue and liver tissue homogenates, pro-inflammatory cytokine expression: tumor necrosis factor- $\alpha$ (TNF- $\alpha$ ), interleukin-6 (IL6), and respiratory parameters: expired volume of ventilation per minute $\left(V_{E}^{*}\right)$, rate of oxygen uptake and amount of carbon dioxide eliminated per minute $\left(\mathrm{V}^{\circ} \mathrm{O}_{2}, \mathrm{~V}^{\circ} \mathrm{CO}_{2}\right)$ during experimentally induced pneumonia (i/p lipopolysaccharides (LPS) injection, $2 \mathrm{mg} / \mathrm{kg}$ ) in rats. Endotoxemia was associated with: (1) pathological changes in lung morphology; (2) increased ROS generation; and (3) a gradual decrease of $V^{\cdot} \mathrm{O}_{2}$ and $V^{\cdot}$ e. Application of multi-component herbal dietary supplement for rats with pneumonia created positive changes in diminishing lung tissue injury, decreasing ROS generation in blood, lung and liver tissue and decreasing pro-inflammatory cytokine expression of TNF- $\alpha$ and Il-6. Oxygen consumption and carbon dioxide elimination in this group was increased compared to the LPS pneumonia group. Results of multi-component herbal dietary supplement treatment of intact animals was mixed: 1) positive - significant increasing of $V^{\circ} \mathrm{O}_{2}$ and $\left.V_{E}^{*} ; 2\right)$ negative - significant augmentation of ROS production in lung tissue. Multi-component herbal dietary supplement manifested promising therapeutic effects in the course of experimental pneumonia. Further research is needed to clarify the mechanisms of its action and the possible applications in clinical medicine.
\end{abstract}

Key words: anti-inflammatory; antioxidant; $V^{\cdot} \mathrm{O}_{2} ; T N F-\alpha$; LPS

\section{INTRODUCTION}

Antibiotic administration in inflammatory disease treatment is often associated with drug resistance [1] and toxicity [2]. Thus discovering active natural (homeopathic) drugs with minimal toxicity, no habituation and positive results on reducing the pathology is a valuable goal for research in medical pharmacology. We created a multi-compositional dietary supplement Vitaphil Lux (technical specification of Ukraine 15.8-32490422-005:2010) (VL), which contains extracts of 19 medicinal plants traditionally used as anti-inflammatory remedies. We included plants known to be powerful antioxidants, as well as ones that suppress expression of pro- inflammatory cytokines. The majority of plants in VL were reported to have strong antioxidant effects. Herbs with a powerful antioxidant action, such as Helichrysum arenarium L. [3], Rheum tanguticum maxim [4], Recuitta chamomile [5], Anethum graveolens L. [6], Calluna vulgaris L., [7], Betonica officinalis L.[8] were all included in our formulation. The basis of the mechanism of antioxidant effect lies in fact that these plants contain considerable amount of flavonoids, which, thanks to the large number of phenolic compounds, have the ability to trap free radicals [9].

The anti-inflammatory effects of VL components are at least partly, related to their

(C) Z. Serebrovska, R. Swanson, V. Portnichenko, A. Shysh, L. Tumanovska, A. Dorovskych, V.Dosenko 
antioxidant properties, since free radical oxidation products stimulate the expression of proinflammatory cytokines. Diminished cytokineinduced neutrophil chemo attractants, IL-1 $\beta$, IL-6, and TNF- $\alpha$ have been described using extracts and active components of Tanacetum vulgare [10], Rheum tanguticum maxim [4], Recuitta chamomile [5], Potentilla anserine L. [10], Valeriana officinalis [11]. Extract of Inula helenium manifests radical-independent inhibition of the nuclear factor- $\kappa \mathrm{B}$ pathway, caused by suppression of the phosphorylation of Syk kinase [12, 13]).

Besides anti-inflammatory and antioxidant properties some components of VL are shown to increase cellular glucose uptake and mitochondrial activity. Increased levels of peroxisome proliferator-activated receptors $\gamma 2$ and reactivation of insulin-mediated phosphorylation of phosphatidyl inositide 3-kinases and AMP-activated protein kinase were described as an effect from extract introduction of 3 items; Inula helenium [14], Recuitta chamomile [5] and Liquorice [15]. Adenosine monophosphate activated protein kinase was shown to regulate diverse metabolic pathways and to increase mitochondrial activity. An increase of mitochondrial enzyme activity occurred with extracts of Potentilla anserine L [11]. Three other plants used in VL improve incretin secretion and, hence, insulin synthesis, and show a hypoglycemic activity; Helichrysum arenarium L. Moench [16], Anethum graveolens L [6] and Melissa officinalis [17].

In this study we investigated the influence of VL on lung tissue morphology, ROS generation in blood, lung-and liver- tissue homogenates, pro-inflammatory cytokines expression (TNFa, IL6) and respiratory parameters $\left(\mathrm{V}_{\mathrm{E}}, \mathrm{V}^{*} \mathrm{O}_{2}\right.$, $\mathrm{V} \cdot \mathrm{CO}_{2}$ ) as we followed the course of our experimental rat pneumonia.

\section{METODS}

The study protocol was approved by the Animal Care Ethics Committee of Bogomoletz Institute of Physiology, Kyiv, Ukraine. Male Wistar rats were maintained in a $12 ; 12 \mathrm{~h}$ light:dark cycle, with a temperature of $22 \pm 3^{\circ} \mathrm{C}$. Food and water were available ad libitum.

VL composition and preparation. Fifty grams of Ledum palustre L.; $50 \mathrm{~g}$ of Helichrysum italicum L.; $30 \mathrm{~g}$ of Helichrysum arenarium L.; 50 $\mathrm{g}$ of Betonica officinalis L.; $25 \mathrm{~g}$ of Valerianaofficinalis L.; $15 \mathrm{~g}$ of Calluna vulgaris L Hill;50 $\mathrm{g}$ of Inula helenium L.; $35 \mathrm{~g}$ of Iris pseudacorus L.; $50 \mathrm{~g}$ of Atropa belladonna L.; $50 \mathrm{~g}$ of Potentilla anserine L.; $50 \mathrm{~g}$ of Melissa officinalis L.; $50 \mathrm{~g}$ of Capsella bursa-pastoris L.; $50 \mathrm{~g}$ of Tanacetum vulgare L.; $45 \mathrm{~g}$ of Artemisia vulgaris L.; $50 \mathrm{~g}$ of Rheum tanguticum maxim.; $50 \mathrm{~g}$ of Chamomilla recutita L. Rauschert (Matricaria chamomillaL.); $30 \mathrm{~g}$ of Glycyrrhizia glabra L.; 30,0 $\mathrm{g}$ of Anethum graveolens L.; $25 \mathrm{~g}$ of Salvia officinalis L. were dried to $20 \%$ humidity, mixed and soak in a mixture of $1000 \mathrm{~g}$ of molasses, with $1000 \mathrm{~g}$ of ethanol at $15{ }^{\circ} \mathrm{C}, 60 \%$ humidity for 7 days. Then $500 \mathrm{ml}$ of distilled water was added to the mixture and heated to $50{ }^{\circ} \mathrm{C}$ for 90 minutes, then cooled and filtered.

Experimental pneumonia. We have chosen pneumonia induced by lipopolysaccharides (LPS) specific to the cell membrane of E. coli as the model for our study. The presence of these structures in the tissues is recognized by the immune system as bacterial invasion which initiates an inflammation cascade. In our experiment LPS was administered via intraperitoneal (i.p) injection. Pneumonia formed in this way is accompanied by sepsis [18]. Rats were injected i.p. with $2 \mathrm{mg} / \mathrm{kg}$ of LPS (Escherichia coli055:B5; Sigma, St. Louis, MO, USA) dissolved in physiological saline, to induce endotoxemia and lung inflammation. Controls were injected with sterile saline alone.

Study design. Thirty-two Wistar 6 month old male rats, weighting 270-350 g, were divided into four groups of 8 rats each: (1) control, (2) experimental pneumonia, (3) experimental pneumonia treated with VL, and (4) VL treatment of intact animals. Animals of all groups were euthanized $72 \mathrm{~h}$ after pneumonia induction 
(LPS injection) and tissue samples were immediately collected. The parameters of pulmonary ventilation and gas exchange were measured five times using respiratory masks fitted to conscious animals as follows: (1)before LPS injection, (2) time zero, (3, 4, and 5) 24, 48 and $72 \mathrm{~h}$ after LPS injection. In control and healthy VL treated groups, pulmonary ventilation and gas exchange were both measured at these times with no additional treatment. Five hundredths $(0.05) \mathrm{ml}$ of VL diluted in sterile water (1:5) was administered 7 times during the study with an orogastric catheter: first at time zero (for the group with pneumonia it was immediately prior to injection of LPS), and then every12 hours.

Histological analysis. All tissues were collected in $2-4 \mathrm{~mm}$ blocks, fixed in $10 \%$ neutral buffered formalin for 24-48 hours, dehydrated, cleared and embedded in paraffin. Four to five $\mu \mathrm{m}$ sections were stained with hematoxylin and eosin (H\&E) and evaluated with light microscopy (Scope: Nikon, Eclipse E-200; camera Nikon, ds-FI1) at 200, 400 and 1,000x for morphological characteristics. Morphometric analysis was performed for samples of four rats from each group. H\&E sections were, conventionally divided into sectors, followed by a random fixation of images analyzed by the software Image J. We analyzed the following parameters:1) relative volume of alveolar space; 2) relative volume of alveolar septa; 3 ) relative volume of hemorrhagic infiltration; 4) relative volume of granulomas; and 5). the relative volume of atelectasis. Results were expressed as a percentage relative to the total volume of each slice of tissue sample.

Reactive oxygen species. ROS generation in blood plasma and lung tissue homogenate was measured by means of lucigenin- and luminolenhanced chemiluminescence (ChL). After decapitation blood was gathered in heparinized tubes and the ChL essay immediately ensued. $500 \mathrm{mg}$ of lung tissue were homogenized on ice in a Potter-Elvehjem tissue grinder with 2,5 $\mathrm{ml}$ of Hanks' balanced salt solution (HBSS). Samples for $\mathrm{ChL}$ measurement contained the fol- lowing ingredients in a total volume of $1 \mathrm{~mL}: 0.9$ $\mathrm{mL}$ of whole blood or lung tissue homogenate; and $0.1 \mathrm{~mL}$ of $50 \mu \mathrm{M}$ lucigenin or $0.1 \mathrm{~mL}$ of 20 $\mu \mathrm{M}$ luminol for the final concentration. After 3-5 min of spontaneous chemiluminescence 0.1 $\mathrm{mL}$ of HBSS with $0.1 \mu \mathrm{g}$ of opsonized zymosan (30 min incubation with rat serum at $37^{\circ} \mathrm{C}$ ) was added to enhance chemiluminescence. Then $\mathrm{ChL}$ was monitored for $15 \mathrm{~min}$ (Luminometer EA-1, Ukraine) at $37^{\circ} \mathrm{C}$ with continuous mixing. We evaluated:1) the light signalsum (S)for $10 \mathrm{~min}$ at a sampling frequency of $0.25 \mathrm{~Hz}$, which was calculated and expressed as relative light units; 2) maximum light signal after $\mathrm{ChL}$ enhancement $\left(\mathrm{I}_{\max }\right)$, expressed as relative light units; and 3) minimal light signal after $\mathrm{ChL}$ enhancement $\left(\mathrm{I}_{\text {min }}\right)$, expressed as relative light units.

ROS generation in liver tissue homogenate was measured by means of $\mathrm{ChL}$ with the Fenton reaction $\left(2 \mathrm{mMFe}^{2+}, 8.8 \mathrm{mM} \mathrm{H}_{2} \mathrm{O}_{2}\right.$ at $\left.\mathrm{pH} 7.4\right)$. Liver tissue was homogenized on ice in a PotterElvehjem tissue grinder with 5 volumes $(\mathrm{w} / \mathrm{v})$ of HBSS. Samples for ChL measurement contained the following ingredients in a total volume of 1 $\mathrm{mL}:$ 1) $0.5 \mathrm{~mL}$ liver tissue homogenate; 2) 0.4 $\mathrm{mL}$ of the $\mathrm{Fe}^{2+}$ solution; and 3) $0.1 \mathrm{~mL}$ of $\mathrm{H}_{2} \mathrm{O}_{2}$. Hydrogen peroxide was added last followed by recording luminescence. ChL was then monitored for 5 min (Luminometer EA-1, Ukraine) at $37^{\circ} \mathrm{C}$ with continuous mixing [19].

RNA isolation, reverse transcription, and real-time polymerase-chain reaction. Total RNA was isolated from lungs using the Trizol RNAprep kit (Isogen, Russian Federation) per the manufacturer's protocol. RNA concentration was determined using a NanoDrop spectrophotometer ND1000 (NanoDrop Technologies Inc, USA). Reverse transcription was performed using a RevertAid ${ }^{\mathrm{TM}} \mathrm{H}$ Minus First Strand cDNA Synthesis Kit (Fermentas, Germany), using $1.2-1.5 \mu \mathrm{g}$ of total RNA and random hexamer primer. Obtained single-stranded DNA was used for real-time polymerase chain reaction (PCR).

Real-time PCR for mRNA expression of genes TNFa, IL6, Cxcl2, and GRO1.

We performed amplification in $10 \mu \mathrm{L}$ of 
SYBR Green PCR Master Mix containing 20 $\mathrm{pM}$ of each primer. For amplifications of TNFa, IL-6and ACTB (corresponding to b-Actin, housekeeping gene) gene fragments, we used the following primers, respectively:TNFaUp:5'CCTCAGCCTCTTCTCATTCCT-3`; TNFa Dw: 5`-GGGAACTTCTCCTCCTTGTTG-3`; IL6 Up: 5'-CAAGAGACTTCCAGCCAGTTG-3’; IL6 Dw: 5'-TGGGTGGTATCCTCTGTGA AG-3`; ACTBUp: 50-TCATCACTATCGGC AATGAGC-30; ACTBDw: 50-GGCCAGGATAGAGCCACCA-30. Sample volume was brought to $20 \mu \mathrm{L}$ with deionized water. Amplification was performed on a 7500 Fast RealTime PCR System. The amplification program consisted of initial AmpliTaq Gold DNA polymerase activation step at $95^{\circ} \mathrm{C}$ for $10 \mathrm{~min}$ and the following 50 cycles: denaturation $\left(95^{\circ} \mathrm{C}\right.$ for $\left.15 \mathrm{~s}\right)$, annealing, and elongation $\left(56^{\circ} \mathrm{C}\right.$ for $\left.60 \mathrm{~s}\right)$. For control of specificity, we performed dissociation stage-sequential increase of temperature from 56 to $99^{\circ} \mathrm{C}$. The drop in the double-stranded DNASYBR Green complexe fluorescence strength was registered. We performed calculations using the 7500 Fast System SDS software provided. The CT (cycle threshold) is defined as the number of cycles required for the fluorescence signal toexceed the detection threshold. We calculated the expression of the target gene relative to the housekeeping gene as the difference between the threshold values of the two genes.

Respiration. The arrangement for measuring ventilatory and gas exchange parameters in rats included a one-way valved mask, a pneumotachograph for small laboratory animals with a pressure sensor (MPX5050), and a mass spectrometer (MH6202, Ukraine) [20]. Signals from the pressure sensor and the mass spectrometer were processed by an analog-digital converter delivered to a computer and analyzed on the custom-written software. As was previously shown [20], the inertia of the mass spectrometer sensor does not affect measurement accuracy under respiratory rate lower than 150 breaths per $\min$. Special calibration curves were used when the respiratory rate reached higher values. We measured respiratory frequency, tidal volume and calculated expired volume of ventilation per minute $\left(\mathrm{V}_{\mathrm{E}}{ }_{\mathrm{E}}\right)$. On the bases of expired $\mathrm{O}_{2}$ and $\mathrm{CO}_{2}$ curves we calculated $\mathrm{V}^{\circ} \mathrm{O}_{2}$ and $\mathrm{V}^{\circ} \mathrm{CO}_{2}$.

These data were expressed in $\mathrm{mL} / \mathrm{min} / \mathrm{kg}$ of body weight to BTPS (body temperature and pressure, saturated system) for respiratory volume and to STPD (standard temperature and pressure, dry system) for metabolic parameters. To exclude circadian metabolism oscillation influences on our results all measured parameters were compared to respective results from intact animals. Data are presented as percent in comparison with referent group.

\section{RESULTS AND DISCUSSION}

Lung morphology. Morphometric analysis of the sections showed that in the group of animals treated with LPS there were disorders characteristic of an inflammatory process in the lung parenchyma. These included hemorrhages, some bronchiolar lumen were filled with cellular masses and exudates, peribronchial tissues were infiltrated with leukocytes with granuloma formation, Emphysematous manifestations were observed including enlarged alveoli, thickened inter alveolar septa due to interstitial edema and leukocyte infiltration, some being broken (Fig. 1). The introduction of LPS significantly increased the relative volume of the alveoli compared with the control. Atelectasis in this group of animals was $10.9 \%$, hemorrhagic infiltration $3.8 \%$, granulomas $1.2 \%$ relative to the total area of the tissue studied (Table 1).

VL treatment of pneumonia significantly reduced lung tissue damage. Although there were some signs of inflammation in this group of animals (hemorrhage areas, leukocyte infiltration into inter-alveolar septa, and local alveolar enlargement (Figure 2)), morphometric analysis showed that the majority of indices returned to normal. The relative area of the sites with atelectasis and hemorrhage decreased to 2.1 and $0.97 \%$, respectively (Table 1 ). The alveolar volume was the same as in the control group. The 

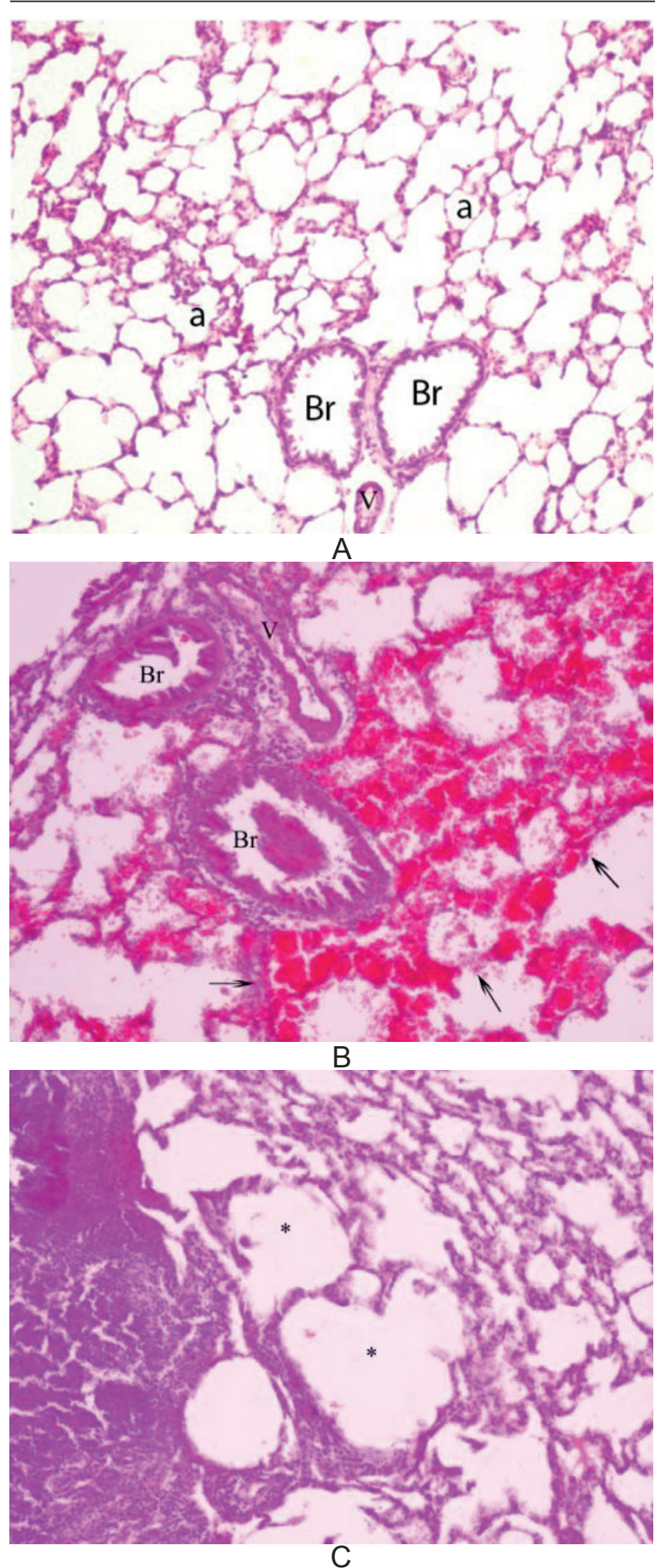

Fig. 1. Lung tissue of rat from control group and after LPS injection. A - Normal lung tissue (x100) of rat from control group. B and C - Lung parenchyma after LPS injection (x 100). $\mathrm{B}$ - Pulmonaryhemorrhage: alveolar spaces containing red cells $(\uparrow)$. Individual bronchioles includeluminal cell masses. Interstitial edema of interalveolar septa: alveoli are filled with exudate and leukocyte components. C - Emphysematous changes of alveoli (*). [Bronchioles (Br), alveoli (a), vessels (V)] area of the granulomas in VL treated pneumonia group $(2.09 \%)$ was slightly increased in comparison with LPS pneumonia untreated group. Introduction of VL to intact animals did not lead to significant changes in the studied parameters. Nevertheless, in this group the relative area of sites with hemorrhages and granulomas was also slightly increased.

Reactive oxygen species. LPS injection caused dramatic changes of all measured parameters in blood plasma. $\mathrm{I}_{\max }, \mathrm{S}$ and $\mathrm{I}_{\min }$ were all significantly increased compared to control. VL treatment of LPS pneumonia resulted in significant reduction of all measured $\mathrm{ChL}$ parameters compared to the LPS group (Table 2). $\mathrm{S}$ and $\mathrm{I}_{\max }$ of lucigenin-dependent $\mathrm{ChL}$ reflects the level of $\mathrm{O}_{2}^{-}$, generation [2 1135$]$, thus, VL treatment diminished LPS-induced $\mathrm{O}_{2}$-overproduction in blood plasma. $\mathrm{I}_{\min }$ decrease indicates improvement of antioxidant capacity and oxidative stress resistance in the blood plasma with VL treatment of LPS-induced pneumonia [22]. A similar enhancement of all $\mathrm{ChL}$ parameters was observed in whole blood (Table 3).

Under VL treatment $\mathrm{S}$ was significantly reduced, while $I_{\max }$ and $I_{\min }$ did not differ from the control. S of luminol-enhanced $\mathrm{ChL}$ reflects the total pool of $\operatorname{ROS}\left(\mathrm{O}_{2}^{-},{ }^{\circ} \mathrm{OH}, \mathrm{H}_{2} \mathrm{O}_{2}\right.$ and other peroxides) generation [21], thus, VL treatment diminished oxidative stress induced by LPS in whole blood. The dynamics of $I_{\text {min }}$ suggest that VL does not yield a positive influence on antioxidant properties of whole blood. The most pronounced effects of LPS injection were observed in lung tissue homogenate, the site of the inflammatory process (Table 4). S and $\mathrm{I}_{\max }$ in lung tissue LPS group were increase to $498 \%$ and $270 \%$ respectively, $I_{\min }$ was increase to $244 \%$. VL treatment led to some diminishment of $\mathrm{S}$ and $\mathrm{I}_{\max }, 30.14 \%$ and $22.1 \%$ respectively, nevertheless these desirable changes were not significant.

LPS injection caused increase ROS production in liver tissue homogenate (Table 5). S, I $\mathrm{Iax}_{\max }$ and $\mathrm{I}_{\min }$ in lever were enhanced to $126.85,84.61$ and $112.53 \%$ respectively compared to control. 
Table 1. Relative volumes of lung tissue morphology parameters as percent of studied area

\begin{tabular}{l|c|c|c|c|}
\hline \multicolumn{1}{c|}{ Parameter } & Control (\%) & LPS (\%) & LPS+VL (\%) & VL (\%) \\
\hline Alveolar volume & $63 \pm 3.63$ & $52.68 \pm 2.95^{*}$ & $59.03 \pm 2.93$ & $60.93 \pm 2.48$ \\
Inter-alveolarseptavolume & $30.45 \pm 3.14$ & $35.55 \pm 6.76$ & $31.45 \pm 4.58$ & $29.4 \pm 2.19$ \\
Atelectasis & $0.08 \pm 0.08$ & $7.53 \pm 7.49$ & $2.18 \pm 2.18$ & $0.73 \pm 0.54$ \\
Hemorrhage & $0.45 \pm 0.45$ & $10.68 \pm 6.6$ & $2.9 \pm 2.9$ & $1.95 \pm 1.95$ \\
Granulomas & $0.05 \pm 0.05$ & $3.51 \pm 3.49$ & $1 \pm 0.68$ & $0.5 \pm 0.5$ \\
\hline
\end{tabular}

$* \mathrm{P}=0,001$ compared to control

VL treatment significantly decreased $\mathrm{S}$ to $35.7 \%$, which reflects diminished oxidative stress in lung tissue.

VL treatment of intact animals caused significant increase in all measured $\mathrm{ChL}$ parameters in blood plasma, whole blood and in lung tissue homogenate. VL seems to enhance superoxide and other ROS production, which exhausts antioxidant reserves in blood and lung tissue. In contradistinction, significant increase of $I_{\max }$ in liver tissue homogenate combined with unchanged $\mathrm{S}$ and $\mathrm{I}_{\min }$. $\mathrm{I}_{\max }$ reflects the level of hydro peroxide production [23 37]. Our results suggest that increased hydro peroxide production is partially compensated by hepatocyte antioxidant activity, which is known to be very

Table 2. Lucigenin-dependent zymosan-induced ChL of blood plasma.

\begin{tabular}{l|c|c|c|}
\hline \multicolumn{1}{c|}{ Groups } & Imax, relative light units & S,relative light units & Imin, relative light units \\
\hline Control & $51.16 \pm 1.7$ & $23038.73 \pm 1115.7$ & $38.16 \pm 1.7$ \\
LPS & $127.5 \pm 4.1^{*}$ & $79234.54 \pm 7874.6^{*}$ & $102.33 \pm 4.3^{*}$ \\
LPS+VL & $93 \pm 7.1^{* *}$ & $58488.96 \pm 4540.4^{* *}$ & $74.57 \pm 6.3^{* *}$ \\
VL & $79.28 \pm 1.6^{*}$ & $47889.33 \pm 6357^{*}$ & $63 \pm 3.7^{*}$ \\
\hline
\end{tabular}

* $\mathrm{P}<0,05$ compared to control, $* * \mathrm{P}<0,05$ compared to LPS group

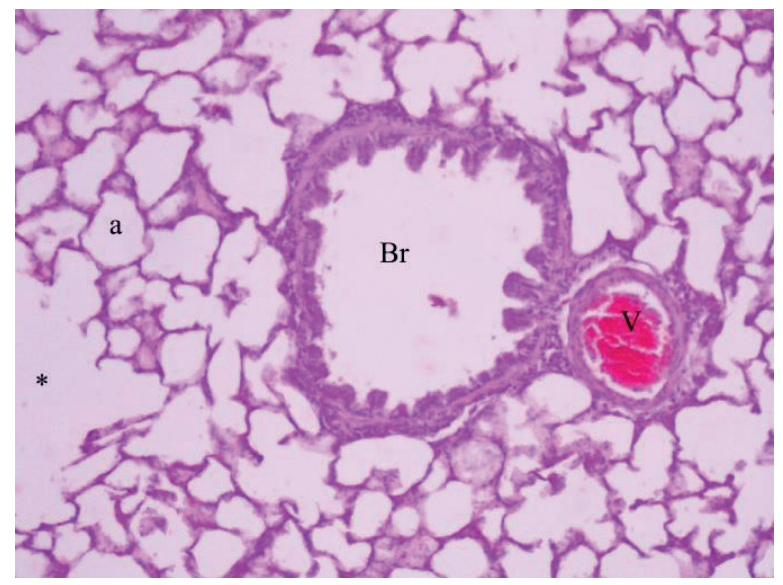

A

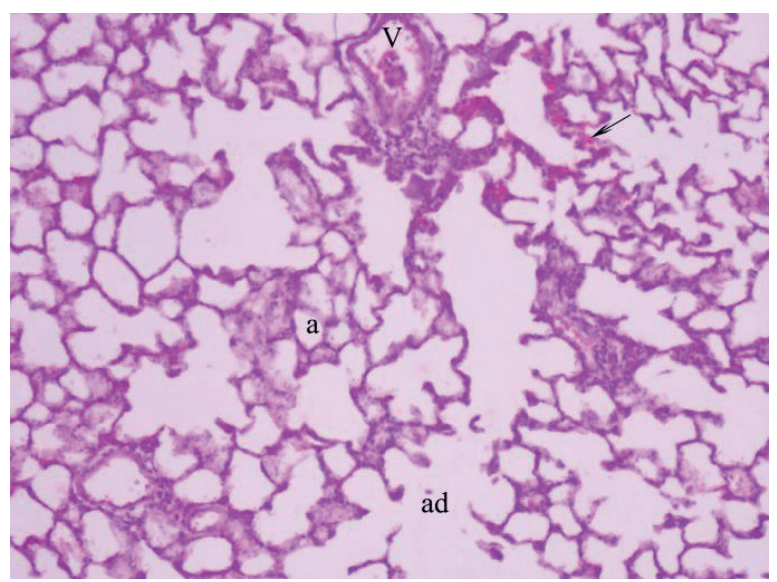

B

Fig. 2. Rat lung after LPS injection and VL treatment (x 100). The lung parenchyma is not disturbed, except for minor infiltration of interalveolar septa and local alveolar dilations (ad), with some emphysematous features $(*)$, as well as sparse hemorrhage areas ( $\uparrow$ ). Br- bronchioles, V-vessels, a - alveoli 
Table 3. Luminol-dependent zymosan-induced ChL of whole blood.

\begin{tabular}{lcccc|}
\hline Groups & $\mathrm{I}_{\max }$, relative light units & S,relative light units & $\mathrm{I}_{\min }$, relative light units \\
\hline Control & $81 \pm 3.9$ & $44414.21 \pm 2550.2$ & $62.16 \pm 4.1$ \\
LPS & $149 \pm 19.0^{*}$ & $96297.96 \pm 11389.1^{*}$ & $119.66 \pm 13.0^{*}$ \\
LPS+VL & $112.42 \pm 12.4$ & $56844.79 \pm 3717^{* *}$ & $92.85 \pm 10.4$ \\
VL & $103.85 \pm 8.6^{*}$ & $59624.03 \pm 4194.8^{*}$ & $88.28 \pm 9.7^{*}$ \\
\hline
\end{tabular}

* $\mathrm{P}<0,05$ compared to control, $* * \mathrm{P}<0,05$ compared to LPS group

powerful compared to antioxidant activity in blood or lung tissue [22].

Cytokine expression. No differences occurred in pro-inflammatory cytokines expression 3 days after LPS injection (Fig. 3). These expected results confirmed that the effect of LPS-induced cytokine expression enhancement was already passed [18]. VL treatment caused significant diminishment of Il-6 and TNF-a expression compared to the LPS group.

Respiration. Development of pneumonia caused gradual decrease of oxygen consumption reaching minimum values at 24 and remaining at the same level at 48 and 72 hours after LPS injection in the LPS group (Fig. 4). The decrease of oxygen consumption was observed also in

Table 4. Lucigenin-dependent zymosan-induced ChL of lung tissue homogenate.

\begin{tabular}{lcccc|}
\hline \multicolumn{1}{c}{ Groups } & $\mathrm{I}_{\max }$, relative light units & S,relative light units & $\mathrm{I}_{\min }$, relative light units \\
\hline Control & $61 \pm 6.08$ & $28015.28 \pm 2304.7$ & $50.5 \pm 6.9$ \\
LPS & $226.28 \pm 23.3^{*}$ & $167588.54 \pm 22891.1^{*}$ & $171.85 \pm 16.0^{*}$ \\
LPS+VL & $176.25 \pm 10.6^{*}$ & $117062.85 \pm 14915.2^{*}$ & $156.25 \pm 12.1^{*}$ \\
VL & $112 \pm 6.1^{*}$ & $87268.92 \pm 12892.5^{*}$ & $93.85 \pm 6.5^{*}$ \\
\hline
\end{tabular}

* $\mathrm{P}<0,05$ compared to control

the VL-treated LPS group at 24 hours after injection, nevertheless, this parameter returned to control level at 48 and 72 hours. VL treatment of intact animals caused a gradual $\mathrm{V}^{\cdot} \mathrm{O}_{2}$ increase with maximum at 72 hours. This effect was accompanied with a $\mathrm{V}^{\cdot} \mathrm{CO}_{2}$ increase, suggesting more intensive carbohydrate and protein metabolism. The decrease in lung ventilation in the LPS group first appeared at 48 hours and then returned to control level at 72 hours after LPS injection (Figure 4). Introduction of VL to LPS injected rats caused a drop of $\mathrm{V}^{\cdot}{ }_{\mathrm{E}}$ at 24 hours after injection and then enhancement of this parameter at 48 hours. Treatment of intact

Table 5. $\left(\mathrm{H}_{2} \mathrm{O}_{2}+\mathrm{Fe}^{2+}\right)$-induced $\mathrm{ChL}$ of liver tissue homogenate.

\begin{tabular}{lcccc|}
\hline \multicolumn{1}{c|}{ Groups } & $\mathrm{I}_{\max }$, relative light units & S,relative light units & $\mathrm{I}_{\min }$, relative light units \\
\hline Control & $412,83 \pm 16,0$ & $11703,26 \pm 542,1$ & $24,33 \pm 2,6$ \\
LPS & $762,14 \pm 63,3^{*}$ & $26548,92 \pm 2793,0^{*}$ & $51,71 \pm 4,3^{*}$ \\
LPS+VL & $722,62 \pm 50,4^{*}$ & $16635,0 \pm 1302,2^{* *}$ & $40,87 \pm 2,8^{*}$ \\
VL & $770,71 \pm 43,2^{*}$ & $12637,56 \pm 286,6$ & $26,57 \pm 1,1$ \\
\hline
\end{tabular}

* $\mathrm{P}<0,05$ compared to control, ${ }^{*} * \mathrm{P}<0,01$ compared to LPS 

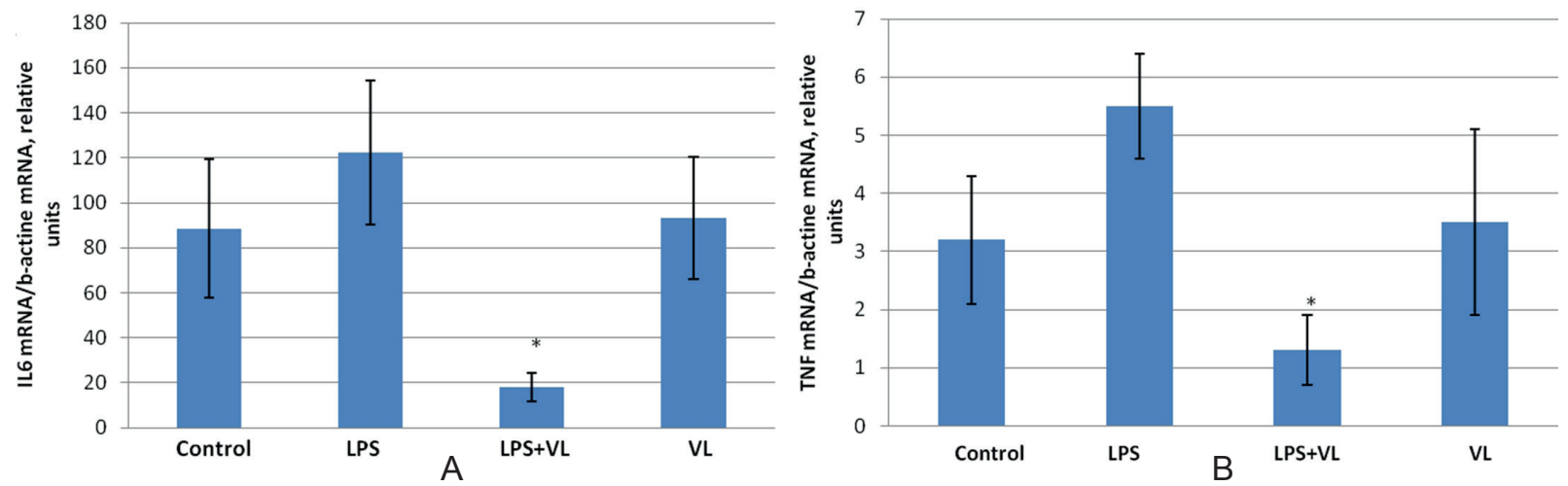

Fig. 3. Expression of IL-6 mRNA(A) and TNF mRNA(B) in lung tissue. Values are means $\pm \mathrm{SE}, * \mathrm{P}<0.05$ compared to LPS

animals with VL led to significant growth of $\mathrm{V}^{\cdot}$ at 72 hours from the start of the experiment.

Data suggest that VL has a therapeutic effect in the course of experimental pneumonia increasing oxygen consumption, lung ventilation and switching metabolism into carbohydrates and protein accumulation. VL treatment also led to enhancement of oxygen consumption in intact animals. The effect of VL is gradual, assumed due to the accumulation of active substances.

Discussion. We have shown that VL has antioxidant and anti-inflammatory effects in the course of experimental pneumonia. VL introduction to the LPS-injected animals protected lung tissue from lesions caused by induced inflammation. We observed diminished atelectasis, interstitial edema, and alveolar volume under VL treatment of pneumonia. These structural changes were accompanied with restoration of oxygen consumption and pulmonary ventilation which originally failed after LPS injection.

We suggest that the mechanisms of VL therapeutic effects are connected with the antioxidant and anti-inflammatory properties of the components. VL treatment reduced LPS induced $\mathrm{O}_{2}{ }^{-}$overproduction in blood plasma, diminished oxidative stress in whole blood and liver tissue homogenate. The non-significant changes were only in lung tissue where inflammation was localized. Nevertheless, the decrease of TNF-a and IL6 expression in lung tissue homogenates suggest that the anti-inflammatory action of VL was also manifested in the lung. The majority of VL compounds contain flavonoids in high concentration, which are the potent ROS scavengers. The hypolipidemic effect of some components of VL, like Valeriana oficinalis [24] and Anethum graveolensL [25] can also be involved in diminishment of blood ROS levels.

The stimulation of oxygen consumption could be considered as an additional possible mechanism of VL therapeutic effect. Stimulation of mitochondrial enzymes is described for Potentilla anserine L. [11]. Moreover, metabolic action of some medicinal plants should be synergistically additive, at least partially, with their antioxidant properties. Extract of Inula helenium increased mitochondrial membrane potential and ATP synthesis due to anti-radical activity [26].

Increase of $\mathrm{CO}_{2}$ elimination suggests increased carbohydrate and protein utilization. Extracts of Inula helenium [14], Recuitta chamomile [5]) and Liquorice [15] were reported to increase cellular glucose uptake. Stimulation of glucose uptake and mitochondrial enzyme activity both improve ATP synthesis and ameliorate recovery of inflamed tissue. The ambiguous effect of VL on intact animals captured our attention. On the one hand we did not observe pathological changes in lung tissue, except for an non-significant increase in granulomatous 

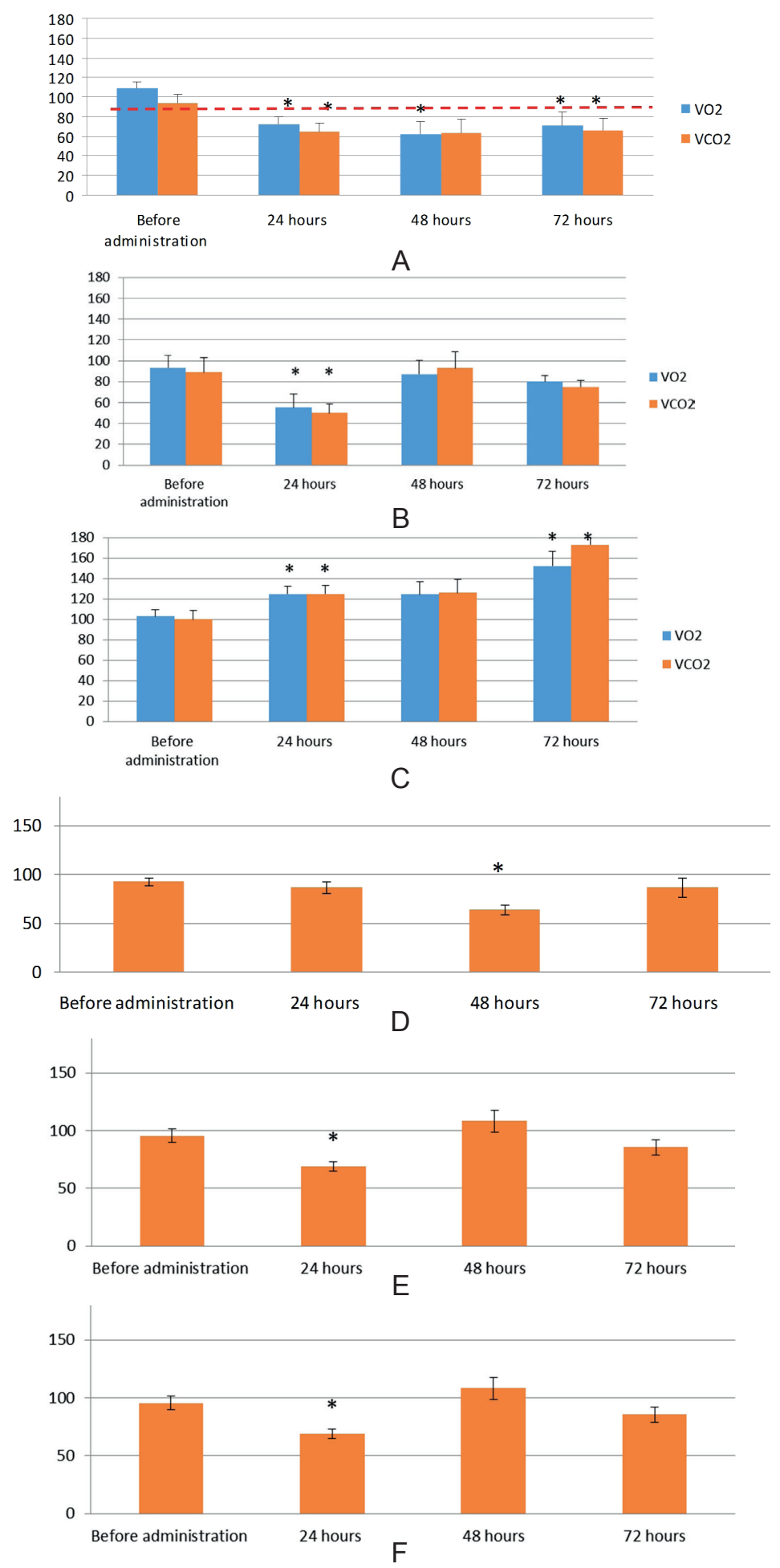

Values are means $\pm \mathrm{SE}, * \mathrm{P}<0.05$ compared to control.

Fig. 4. Dynamics of $\mathrm{V}^{\cdot} \mathrm{O}^{2}, \mathrm{~V}^{\cdot} \mathrm{CO}^{2}$ and $\mathrm{V}^{\cdot} \mathrm{E}$ in different groups. $\mathrm{A}-\mathrm{V}^{\cdot} \mathrm{O}^{2}$ and $\mathrm{V}^{\cdot} \mathrm{CO}^{2}$ in $\mathrm{LPS}$ pneumonia, $\mathrm{B}-\mathrm{V}^{\cdot} \mathrm{O}^{2}$ and $\mathrm{V}^{\cdot} \mathrm{CO}^{2}$ in $\mathrm{VL}$ treatment of LPS pneumonia. $\mathrm{C}-\mathrm{V}^{\cdot} \mathrm{O}^{2}$ and $\mathrm{V}^{\cdot} \mathrm{CO}^{2}$ in $\mathrm{VL}$ treatment of intact animals, D- $\mathrm{V}^{*} \mathrm{E}$ in LPS pneumonia, E- $\mathrm{V}^{*} \mathrm{E}$ in $\mathrm{VL}$ treatment of LPS pneumonia, F- V'E in VL treatment of intact animals 
areas. No increase of cytokine production or inflammation was observed. We measured a stimulation in oxygen consumption. On the other hand, VL treatment of intact animals caused significant increase in all measured $\mathrm{ChL}$ parameters in blood plasma, whole blood and in lung tissue homogenates. In the liver this effect was less pronounced, presumably due to increased resistance of hepatocytes to oxidative stress. One possible explanation of such phenomena is the increased superoxide production by activated mitochondria. Another scenario is connected to the pro-oxidative action of some VL compounds. In addition antiinflammatory properties of Tanacetum vulgare [27], Inula helenium L [28], Melissa officinalis [17], Artemisia vulgaris L [29] can all increase oxidative stress and induce mitochondrial-related apoptosis. These compounds have been traditionally used in anti-cancer therapy. VL manifested promising therapeutic effects in experimental pneumonia. Further research is needed to clarify the mechanisms of its action, the primary effectors in this multi-faceted compound and possible applications in medicine.

\section{CONCLUSION}

VL manifested promising therapeutic effects in the course of experimental pneumonia. VL treatment of rats with pneumonia created positive changes in diminishing lung tissue injury, decreasing ROS generation in blood, lung and liver tissue, decreasing pro-inflammatory cytokine expression of TNF- $\alpha$ and I1-6 and improving oxygen consumption and carbon dioxide elimination. Results of VL treatment of intact animals was mixed: 1 ) positive - significant augmentation of $\mathrm{V}^{\circ} \mathrm{O}_{2}$ and $\mathrm{V}^{\cdot} \mathrm{E} ; 2$ ) negative significant augmentation of ROS production in lung tissue. Further research is needed to clarify the mechanisms of its action and the possible applications in clinical medicine.

Acknowledgement.

This research was funded by National Academy of Sciences of Ukraine.
The authors of this study confirm that the research and publication of the results were not associated with any conflicts regarding commercial or financial relations, relations with organizations and/or individuals who may have been related to the study, and interrelations of coauthors of the article.

\section{3. Серебровська ${ }^{1}$, Р. Свонсон ${ }^{2}$, В. Портніченко ${ }^{1}$, А. Шиш ${ }^{1}$, Л. Тумановська ${ }^{1}$, А. Доровських ${ }^{3}$, В. Досенко ${ }^{1}$ \\ ЕФЕКТИ ТРАВ' ЯНОЇ БАГАТОКОМПОНЕНТ- НОЇ ДІЄТИЧНОЇ ДОБАВКИ ПРИ ЕКСПЕРИ- МЕНТАЛЬНІЙ ПНЕВМОНІї.}

Ми досліджували дію багатокомпонентної трав'яної дієтичної добавки, яка містить екстракти з 19 лікарських рослин, традиційно використовуваних як протизапальні засоби, на морфологію легеневої тканини, генерацію активних форм кисню (АФК) в крові, та гомогенатах тканини печінки та легень, експресію прозапальних цитокінів: tumor necrosis factor- $\alpha$ (TNF- $\alpha$ ) та interleukin-6 (IL6), та параметри зовнішнього дихання: хвилинний об'єм вентіляції $\left(\mathrm{V}^{*}{ }_{\mathrm{E}}\right)$, хвилинне поглинання кисню $\left(\mathrm{V}^{*} \mathrm{O}_{2}\right)$ та виділення вуглекислого газу за хвилину $\left(\mathrm{V}^{\cdot} \mathrm{CO}_{2}\right)$ під час експериментально індукованої пневмонії (ін'єкція ліпополісахаридів, 2 мг / кг) у щурів. Ендотоксемія була пов'язана 3: патологічними змінами в морфології легенів; збільшенням генерації АФК; і поступовим зменшенням $\mathrm{V}^{\cdot} \mathrm{O}_{2}$ та $\mathrm{V}_{\mathrm{E}} \cdot$. Застосування добавки для щурів із пневмонією спричинило позитивні зміни: зниження інтенсивності пошкоджень легеневої тканини, генерації АФК в крові, тканинах легень та печінки, та зниження експресії прозапальних цитокінів TNF- $\alpha$ та Il-6. $\mathrm{V}^{\cdot} \mathrm{O}_{2}$ и $\mathrm{V}_{\mathrm{E}}{ }_{\mathrm{E}}{ }^{\mathrm{B}}$ цій групі були збільшені порівняно зі значеннями у щурів $з$ ліпополісахаридною пневмонією. Результати застосування добавки для лікування інтактних тварин були змішані: позитивні - значне збільшення $\mathrm{V}^{*} \mathrm{O}_{2}$ та $\mathrm{V}_{\mathrm{E}}^{\cdot}$; негативні - значне збільшення вироблення АФК у легеневій тканині. Добавка виявляє перспективні терапевтичні ефекти під час експериментальної пневмонії. Потрібні подальші дослідження, щоб з'ясувати механізми iї дії та можливі застосування в клінічній медицині.

Ключові слова: протизапальний; антиоксидантний; поглинання кисню; фактор некрозу пухлини- $\alpha$; ліпополісахариди

${ }^{1}$ Інститут фізіології ім. Богомольия НАН Украӥни, Київ, Україна; e-mail: belyak-serebrovska@hotmail.com;

${ }^{2}$ Університет Ліберті, Остеопатична Медицина, Лінчбург, США;

${ }^{3}$ Інтегративна клініка «Смартмед», Київ, Україна 
3. Серебровская, Р. Свонсон, В. Портниченко, А. Шиш, Л. Тумановская, А. Доровских, В. Досенко

\section{ЭФФЕКТЫ ТРАВЯНОЙ МНОГОКОМПО- НЕНТНОЙ ДИЕТИЧЕСКОЙ ДОБАВКИ ПРИ ЭКСПЕРИМЕНТАЛЬНОЙ ПНЕВМОНИИ.}

Мы исследовали влияние многокомпонентной травяной диетической добавки, которая содержит экстракты 19 лекарственных растений, традиционно используемых в качестве противовоспалительного средства на морфологию легочной ткани, генерацию активных форм кислорода (АФК) в крови, и гомогенатах ткани печени и легких, экспрессию провоспалительных цитокинов: tumor necrosis factor- $\alpha$ (TNF- $\alpha$ ) и interleukin-6 (IL6), и параметры внешнего дыхания: минутный объем вентиляции $\left(\mathrm{V}_{\mathrm{E}}{ }_{\mathrm{E}}\right)$, минутное поглощение кислорода $\left(\mathrm{V}^{*} \mathrm{O}_{2}\right)$ и выделение углекислого газа за минуту $\left(\mathrm{V}^{\cdot} \mathrm{CO}_{2}\right)$ при экспериментальной пневмонии (инъекция липополисахаридов, 2 мг / кг) у крыс. Эндотоксемия была связана с: патологическими изменениями в морфологии легких; увеличением генерации АФК; и постепенным уменьшением $\mathrm{V}^{\cdot} \mathrm{O}_{2}$ и $\mathrm{V}_{\mathrm{E}}{ }_{\mathrm{E}}$. Применение добавки для крыс с пневмонией привело к положительным изменениям: уменьшению повреждений легочной ткани, уменьшению генерации АФК в крови, тканях легких и печени и снижению экспрессии провоспалительных цитокинов TNF- $\alpha$ и IL-6. $\mathrm{V}^{*} \mathrm{O}_{2}$ и $\mathrm{V}_{\mathrm{E}}{ }_{\mathrm{E}}$ в этой группе были увеличены по сравнению со значениями у крыс с липополисахаридной пневмонией. Результаты применения добавки для лечения интактных животных были смешанные: положительные - значительное увеличение $\mathrm{V}^{\cdot} \mathrm{O}_{2}$ и $\mathrm{V}_{\mathrm{E}}^{*}$; отрицательные - значительное увеличение выработки АФК в легочной ткани. Многокомпонентная травяная диетическая добавка оказывает перспективные терапевтические эффекты при экспериментальной пневмонии. Требуются дальнейшие исследования, чтобы выяснить механизмы ее действия и возможные применения в клинической медицине.

Ключевые слова: противовоспалительный; антиоксидантный; потребление кислорода; фактор некроза опухоли- $\alpha$; липополисахариды

\section{REFERENCES}

1. Hnin K, Nguyen C, Carson KV, Evans DJ, Greenstone M, Smith BJ. Prolonged antibiotics for non-cystic fibrosis bronchiectasis in children and adults. Cochrane Database Syst Rev. 2015 Aug 13;(8):CD001392

2. Oudenhoven MD, Kinney MA, McShane DB, Burkhart $\mathrm{CN}$, Morrell DS. Adverse effects of acne medications: recognition and management Am J Clin Dermatol. 2015 Aug;16(4):231-42

3. Sroka Z,Kuta I,Cisowski W, Dryś A. Antiradical activity of hydrolyzed and non-hydrolyzed extracts from Helichrysiin florescentia and its phenolic contents. Z Naturforsch C. 2004 May-Jun;59(5-6):363-7.
4. Hu G, Liu J, Zhen YZ, Xu R, Qiao Y, Wei J, Tu P, Lin YJ. Rheinlysinate increases the median survival time of SAMP10 mice: protective role in the kidney. Acta Pharmacol Sin.2013 Apr;34(4):515-21.

5. Miraj S, Alesaeidi S. A systematic review study of therapeutic effects of Matricaria recuitta chamomile (chamomile). Electron Physician. 2016 Sep 20;8(9):3024-3031.

6. Kazemi M. Phenolic profile, antioxidant capacity and antiinflammatory activity of Anethum graveolens L. essential oil. Nat Prod Res.2015;29(6):551-3.

7. Olteanu D, Baldea I, Clichici S , Bolfa P, Cenariu M, Schrepler-Perde M, Alupei M, Muresan A, Filip A. In vitro studies on the mechanisms involved in chemoprevention using Calluna_vulgaris on vascular endothelial cells exposed to UVB. J Photochem Photobiol B. 2014 Jul 5;136:54-61.

8. Konieczyński P. Electrochemical fingerprint studies of selected medicinal plants rich in flavonoids. Acta Pol Pharm.2015 Jul-Aug;72(4):655-61.

9. Mazzio EA, Bauer D, Mendonca P, Taka E,Soliman KF. Natural product HTP screening for attenuation of cytokine-induced neutrophil chemo attractants (CINCs) and NO2- in LPS/IFN $\gamma$ activated glioma cells. J Neuroimmunol. 2017 Jan 15;302:10-19.

10. Paduch R, Wiater A, Locatelli M, Pleszczyńska M, Tomczyk M Aqueous Extracts of Selected Potentilla Species Modulate Biological Activity of Human Normal Colon Cells. Curr Drug Targets. 2015;16(13):1495-502.

11. Sridharan S, Mohankumar K, Jeepipalli SP, Sankaramourthy D, Ronsard L, Subramanian K, Thamilarasan M, Raja K, Chandra VK, Sadras SR. Neuroprotective effect of Valeriana wallichii rhizome extract against the neurotoxin MPTP in C57BL/6 mice. Neurotoxicology.2015 Dec;51:172-83.

12. Lu Y, Li X, Park YN, Kwon O, Piao D, Chang YC, Kim $\mathrm{CH}$, Lee E, Son JK, Chang HW. Britanin Suppresses IgE/ Ag-Induced Mast Cell Activation by Inhibiting the Syk Pathway. Biomol Ther (Seoul).2014 May;22(3):193-9

13. Park HH, Kim SG, Park YN,Lee J, Lee YJ, Park NY,Jeong KT, Lee E Suppressive effects of britanin, a sesquiterpene compound isolated from Inulaeflos, on mast cell-mediated inflammatory responses. Am J Chin Med. 2014;42(4):935-47.

14. Seca AM, Grigore A,Pinto DC,Silva AM. The genus Inula and their metabolites: from ethnopharmacological to medicinal uses. J Ethnopharmacol.2014 Jun 11;154(2):286-310

15. Simmler C, Pauli GF, Chen SN. Phytochemistry and biological properties of glabridin. Fitoterapia. 2013 Oct;90:160-84.

16. MorikawaT, NinomiyaK, AkakiJ, KakiharaN, KuramotoH, MatsumotoY, HayakawaT, MuraokaO, WangLB, WuLJ, NakamuraS, YoshikawaM, MatsudaH. Dipeptidyl peptidase-IV inhibitory activity of dimeric dihydrochalcone glycosides from flowers of Helichrysumarenarium. J Nat Med. 2015 Oct;69(4):494-506

17. Shakeri A, Sahebkar A, Javadi B. Melissa officinalis L. - 
A review of its traditional uses, phytochemistry and pharmacology. J Ethnopharmacol. 2016 Jul 21;188:204-28.

18. Demiralay R, Gürsan N, Erdem H Regulation of sepsisinduced apoptosis of pulmonary cells by posttreatment of erdosteine and N-aceylcysteine. Toxicology. $2006 \mathrm{Dec}$ 7;228(2-3):151-61.

19. Goldstein S, Meyerstein D, Czapski G (1993) The Fenton reagents. Free Rad Biol Med 15:435-445.

20. Pozharov VP Automatic installation for measuring the volume-time parameters of external respiration and gas exchange in small laboratory animals. FiziolZh. 1989 Jul-Aug;35(4):119-21.

21. Žilinskas J, Žekonis J, Žekonis G, Šadzevičienė R, SapragonienėM, NavickaitėJ, BarzdžiukaitėI. Inhibition of peripheral blood neutrophil oxidative burst in periodontitis patients with a homeopathic medication Traumeel S. MedSciMonit. 2011; 17(5): CR284-CR291.

22. Antonini JM, Van Dyke K, Ye Z, Di Matteo M, Reasor MJ. Introduction of luminol-dependent chemiluminescence as a method to study silica inflammation in the tissue and phagocytic cells of rat lung.Environ Health Perspect. 1994,102 Suppl 10:37-42.

23. Piskarev IM, Trofimova SV, Burkhina OE, Ivanova IP Investigation of Free Radical Processes in Substrates and Biological Samples by Means of induced Chemiluminescence Biofizika.2015;60(3):496-505.

24. Zhu J, Xu K, Zhang X, Cao J, Jia Z, Yang R, Ma C, Chen $\mathrm{C}$, Zhang T, Yan Z. Studies on the regulation of lipid metabolism and its mechanism of the iridoids rich fraction in Valerianajatamansi Jones. BiomedPharmacother.2016 Dec;84:1891-1898.

25. Goodarzi MT, Khodadadi I, Tavilani H, Abbasi Oshaghi E The Role of Anethum graveolens L. (Dill) in the Management of Diabetes. J Trop Med.2016;2016:1098916.

26. Wang J,Zhao YM,Zhang B,Guo CY.Protective Effect of Total Phenolic Compounds from Inula helenium on Hydrogen Peroxide-induced Oxidative Stress in SH-SY5Y Cells. Indian J Pharm Sci.2015 MarApr;77(2):163-9.

27. Negrín G, Rubio S, Marrero MT, Quintana J, Eiroa JL, Triana J, Estévez F. The eudesmanolidetanapsin from Tanacetum oshanahanii and its acetate induce cell death in human tumor cells through a mechanism dependent on reactive oxygen species. Phytomedicine. 2015 Mar 15;22(3):385-93.

28. Du Y, Gong J, Tian X, Yan X, Guo T, Huang M, Zhang B, Hu X, Liu H, Wang Y, Li J, Li M.Japonicone A inhibits the growth of non-small cell lung cancer cells via mitochondria-mediated pathways. Tumour Biol. 2015 Sep;36(10):7473-82.

29. Alesaeidi S, Miraj S. A Systematic Review of Antimalarial Properties, Immunosuppressive Properties, Anti-inflammatory Properties, and Anti-cancer Properties of Artemisia Annua. Electron Physician.2016 Oct 25;8(10):3150-3155. 